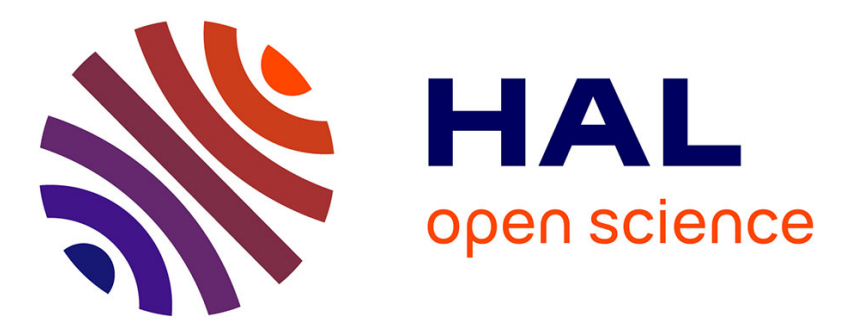

\title{
Demographic parameters of reintroduced grey partridges in central Italy and the effect of weather
}

\author{
A. Vidus Rosin, A. Meriggi, F. Pella, M. Zaccaroni
}

\section{To cite this version:}

A. Vidus Rosin, A. Meriggi, F. Pella, M. Zaccaroni. Demographic parameters of reintroduced grey partridges in central Italy and the effect of weather. European Journal of Wildlife Research, 2009, 56 (3), pp.369-375. 10.1007/s10344-009-0329-5 . hal-00535258

\section{HAL Id: hal-00535258 \\ https://hal.science/hal-00535258}

Submitted on 11 Nov 2010

HAL is a multi-disciplinary open access archive for the deposit and dissemination of scientific research documents, whether they are published or not. The documents may come from teaching and research institutions in France or abroad, or from public or private research centers.
L'archive ouverte pluridisciplinaire HAL, est destinée au dépôt et à la diffusion de documents scientifiques de niveau recherche, publiés ou non, émanant des établissements d'enseignement et de recherche français ou étrangers, des laboratoires publics ou privés. 


\title{
Demographic parameters of reintroduced grey partridges in central Italy and the effect of weather
}

\author{
A. Vidus Rosin $\cdot$ A. Meriggi $\cdot$ F. Pella $・$ M. Zaccaroni
}

Received: 2 March 2009/Revised: 18 September 2009/Accepted: 24 September 2009/Published online: 9 October 2009

(C) Springer-Verlag 2009

\begin{abstract}
Grey partridge populations declined in Europe from mid-1950s onwards mostly due to modifications of agricultural cropping. In Italy, the decline was even more dramatic because of over-hunting and restocking with allochthonous birds. We carried out a research on a reintroduced population in Central Italy from 1995 to 2005, with the aim of evaluating the reintroduction success and separating the intrinsic and external factors influencing year-to-year changes in partridge density with particular respect to the weather. Average spring density was 4.5 pairs per square kilometre $(\mathrm{SD}=1.52)$; our population reached a peak few years after the reintroduction and then declined. Brood production rate was close to that of declining European populations (average $33.9 \% ; \mathrm{SD}=10.21$ ), and chick survival rate (average $40 \% ; S D=17.61$ ) determined the change of breeding abundance from year $t$ to year $t+1$. Our population seemed to be mainly affected by brood production and chick survival rates and by the weather; in particular, higher early winter and spring temperatures increased breeding density whilst higher early summer temperatures decreased brood production rate.
\end{abstract}

Keywords Perdix perdix · Reintroduction success ·

Annual changes $\cdot$ Weather

Communicated by W. Lutz

A. Vidus Rosin $\cdot$ A. Meriggi $(\bowtie) \cdot$ F. Pella

Department of Animal Biology, University of Pavia,

Piazza Botta 927100 Pavia, Italy

e-mail: meriggi@unipv.it

M. Zaccaroni

Department of Animal and Man Biology, University of Florence,

Via Romana 17,

Florence, Italy

\section{Introduction}

The European populations of Grey partridge (Perdix perdix Linnaeus 1758) declined from mid-1950s onwards with the reduction and the marked fragmentation of their historical range, especially along the range boundaries (Potts 1986; Potts and Aebischer 1994; Putaala and Hissa 1998; Meriggi et al. 2002; Aebischer and Ewald 2004; De Leo et al. 2004; Panek 2005; Meriggi et al. 2007). Population decreases occurred to such an extent that the species was considered threatened and vulnerable and was classified in the list of the Species of European Conservation Concern in the third category (i.e. species with an unfavourable conservation status, with populations that are not concentrated in Europe; Tucker and Heath 1994; Aebischer and Kavanagh 1996).

The main recognised cause of the decline of grey partridge numbers in Europe is the modification of agricultural cropping following the mechanisation of agricultural practices and the use of pesticides, thus reducing farmland biodiversity with effects on habitat and food resources (Potts 1980, 1986). In particular, modern agriculture reduces preferred nesting cover and the abundance of insects that are the preferred food for chicks, thus reducing in turn nesting success and chick survival and increasing breeding predation pressure in simplified agroecosystems (Meriggi et al. 1992; Panek 1997a, b, 2005; Frampton and Dorne 2007; Potts 2008). In some countries, other factors are also involved in the grey partridge decline and fluctuations. In France, Bro et al. (2000, 2003, 2005) found evidence that higher adult mortality due to predation by the hen harrier contributed to lower grey partridge numbers. In Poland, in the 1960s and 1970s, populations of grey partridges fluctuated widely, mainly as a result of decreases after severe winters (Chlewski and Panek 1988; Pielowski and Pinkowski 1988). Meriggi et al. (1992) 
reported the negative influence of only two subsequent severe winters on breeding density of wild partridges in northern Italy and related the fall density to chick survival rate (CSR) and this, in turn, to early summer weather. In northern France, Ricci and Garrigues (1986) linked the proportion of females without chick and the survival of young to winter, early spring and summer temperatures. Then, Reitz (1988) modelled Grey partridge breeding success by the rainfall intensity and evaporation in June.

In Italy, the decline of grey partridge populations started later than in Western Europe, due to the delayed adoption of modern farming practices. However, the eventual decline was even more dramatic because also over-hunting acted on the already reduced productivity of populations caused by the environmental changes and by the increased use of herbicides and pesticides (Potts 1985; De Leo et al. 2004; Watson et al. 2007), which rendered the species endangered in a few years (Matteucci and Toso 1986; De Franceschi 1988; Meriggi et al. 2007). Attempts to counteract the decline by restocking speeded up the process; in fact, initially, partridges from eastern Europe were used, which did not adapt to the local ecological conditions, and afterwards, releases of hand-reared partridges were carried out causing a further decrease in the productivity of wild populations (Putaala and Hissa 1998). Now, in Italy, probably there are still large areas characterised by high habitat suitability, where the grey partridge went extinct and where the species might be reintroduced successfully. However, the lack of wild populations require the use of hand-reared birds for reintroductions, which have great acclimatisation difficulties due to the genetic and behavioural differences between wild and reared partridges, to the physiological and disease problems and to density-dependent predation at the release sites (Dowell 1992; Parish and Sotherton 2007; Buner and Schaub 2008; Sokos et al. 2008).

This research was carried out from 1995 to 2005 on a population of grey partridges reintroduced in the province of Siena (Central Italy), with the aim of evaluating the reintroduction success and separating the intrinsic and external factors affecting demographic parameters during a period in which farmland landscape was constant but where the weather changed greatly.

\section{Materials and methods}

\section{Study area}

The study area $\left(26.5 \mathrm{~km}^{2}, 42^{\circ} 59^{\prime} 44.01^{\prime \prime} \mathrm{N}, 1^{\circ} 39^{\prime} 31.47^{\prime \prime} \mathrm{E}\right)$ was located in the province of Siena, in Tuscany (Central Italy; Fig. 1). Topography was mainly gently to moderately undulating with elevations of 200-500 masl. Land use was predominantly winter cereals (61.1\% from 1995 to 2005$)$ and field beans (Vicia faba minor) and clovers (13.1\%); olive groves, vineyards and orchards averaged $8.3 \%$. A small percentage of the study area was covered by game cover crops (alfalfa, fallow strips, $0.9 \%$ ), set aside $(5.4 \%)$, pasture $(1.4 \%)$, woods $(0.6 \%)$ and shrubs $(6.3 \%)$. Farmsteads were scattered in the area, and villages were located on the border; they covered on average $2.7 \%$ of the study area. Considering all land use classes, mean patch size and edge length were respectively 1.1 ha $(\mathrm{SD}=3.01)$ and $42.5 \mathrm{~km} / \mathrm{km}^{2}$, whereas considering only crops, the mean fields size was 2.4 ha $(\mathrm{SD}=$ 4.5) and edge length $26.5 \mathrm{~km} / \mathrm{km}^{2}$. Climate was subMediterranean, with mild winters and hot summers. The average annual temperature was $14.7^{\circ} \mathrm{C}$ (minimum in January, $5.5^{\circ} \mathrm{C}$; maximum in July, $23.9^{\circ} \mathrm{C}$ ). Annual precipitation was $500 \mathrm{~mm}$, with two peaks, one in April and one in November, and a minimum in July.

In the study area, 420 hand-reared grey partridges were released in spring and autumn 1995 and 175 in winter 1996. All birds were from local game farms and released in small groups of 10-15 individuals with acclimatisation aviaries scattered over the area (38 release sites). To increase the survival and reproductive success of released birds, 50 feeding sites were scattered in the study area and equipped with automatic feeders and watering troughs. Moreover, hooded crows (Corvus coronae cornix) and magpies (Pica pica) were controlled using Larsen traps (14.8 crows per year, $\mathrm{SD}=5.00 ; 35.8$ magpies per year, $\mathrm{SD}=13.55$ ) and foxes (Vulpes vulpes) by night-shooting ( 55.5 foxes per year, $\mathrm{SD}=7.05$ ). In the study area, partridge hunting was forbidden.

\section{Population monitoring}

The reintroduced population was monitored by censuses of pairs in March to April and broods in July to August, carried out by the mapping method (Blondel 1969; Pépin 1983). Searching effort was equally distributed by a net of transects $(2.1 \mathrm{~km}$ per square kilometre) that covered the whole study area. Surveys were carried out during the first $3 \mathrm{~h}$ after dawn and the last three before dusk in the times of greatest detectability of partridges. A tape-recorded call was used in spring to increase the pair detectability (Pépin 1983; Ricci 1985; Meriggi 1989; Gibbons et al. 1996). Observations and calling birds were mapped at 1:10,000 scale.

The following population parameters were calculated: (1) pair and brood density $\left(n / \mathrm{km}^{2}\right)$; (2) population change (\%) from year $t$ to year $t+1$ (Aebischer and Ewald 2004); (3) brood production rate (BPR), as percent ratio of brood to pair number (i.e. the percentage of pairs reproducing successfully); (4) mean brood size (arithmetic and geomet- 
Fig. 1 Location of the study area (central Italy)

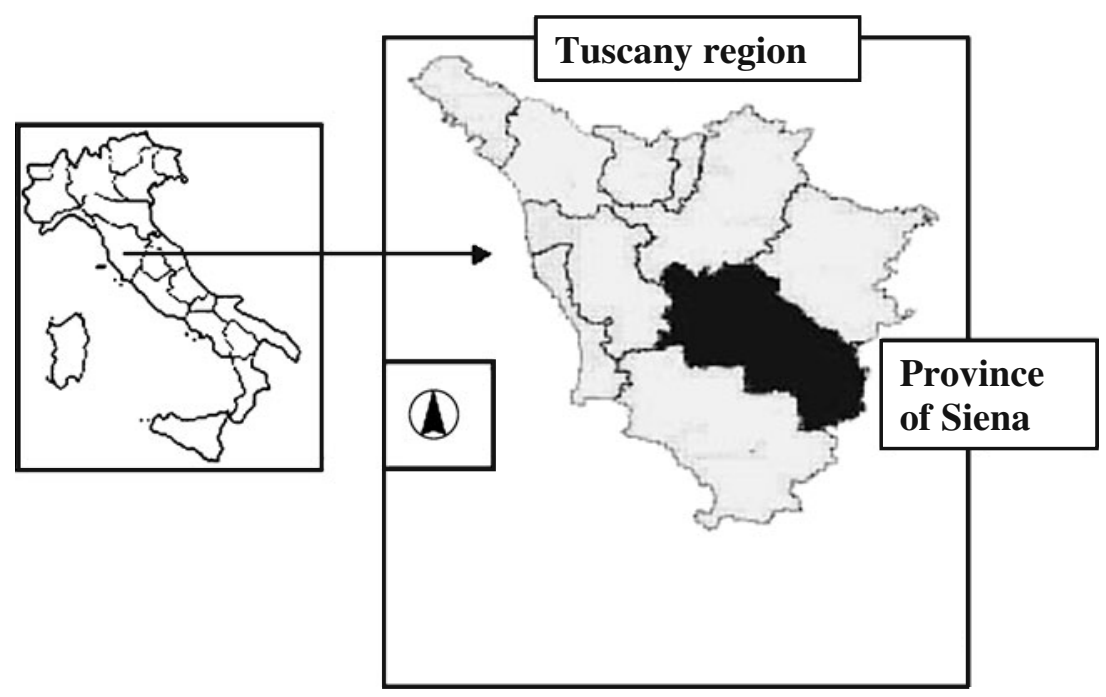

ric mean); (5) CSR, calculated from the geometric mean of the brood size (Potts 1980, 1986); and (6) juvenile density (>60 days old).

\section{Weather}

Weather data for each study year were obtained from four climatic stations close to the study area $(5.3 \mathrm{~km}$ on average far from it; Tuscany Region Agro-meteorological Service; 2005). We collected daily data and then calculated the following weather components for every month: (1) average temperature $\left({ }^{\circ} \mathrm{C}\right),(2)$ absolute minimum temperature, (3) absolute maximum temperature, (4) average rainfall (mm), (5) number of rainy days and (6) average humidity (\%).

\section{Statistical analyses}

We estimated the average growth ratio $(r)$ of the population by linear regression analyses of $\ln$ of the pair number and time (years) (Caughley and Sinclair 1994). We employed correlation coefficients (Pearson product moment): (1) to test for association among weather variables, thus using non-correlated variables for the following analyses, and (2) to study the relationships among demographic parameters. Moreover, we computed partial correlation coefficients to examine the net effect of weather variables on demographic parameters. In the case of multiple correlations, we calculated the $p$ values by truncated product method (TPM, $p$ value) instead of applying Bonferroni's correction because of the recent criticisms to this method (Zaykin et al. 2002, Moran 2003, Garcia 2004, Neuhauser 2004). Finally, curve-fit analyses were used to choose the best model fitting the observed data. Statistical analyses were performed by SPSS/PC+Version 15.0.

\section{Results}

Population dynamics

Grey partridge spring population increased until 2001 by $98.9 \%$, with an average growth rate of $r=0.1$ ( $\mathrm{SE}=$ 0.05 ), followed by a dramatic decrease of $65.5 \%$ during the last 5 years of the study period $(r=-0.3 ; S E=0.06 ; Y=$ $72.9+34.1 x-3.7 x^{2}, r^{2}=0.712, p=0.013$; Table 1). Pair density averaged 4.5 pairs per square kilometre $(\mathrm{SD}=$ $1.52)$ and was positively related to juvenile density of the previous year $(r=0.802, n=9, p=0.009$; TPM $p$ value $=$ 0.020 ) by a linear model that explained $64.4 \%$ of the variance $(Y=1.9+0.3 x)$. Brood density averaged 1.5 broods per square kilometre from 1995 to $2004(\mathrm{SD}=$ $0.74)$ and was positively related with pair density $(r=$ $0.774, n=9, p=0.014)$. The linear model of brood density vs. pair density explained nearly $59.9 \%$ of the total variance $(Y=2.3+1.5 x)$. Average BPR was $33.9 \%$ in the period 1996-2004 $(\mathrm{SD}=10.21)$, and its dependence on pair density was not significant $(r=-0.034, n=9, p=$ 0.931). CSR averaged $40 \%(\mathrm{SD}=17.61)$ from 1995 to 2004. The juvenile density was 9.2 per square kilometre $(\mathrm{SD}=4.23)$ on average from 1996 to 2004 . The change in abundance of spring population from 1 year to the next was positively related to CSR $(r=0.762, n=9, p=$ 0.017 ; TPM $p$ value $=0.035$ ) by a linear model that explained $58 \%$ of the total variance. Population change was negative with CSRs lower than $39 \%$ and positive at higher CSRs (Fig. 2). Neither the BPR nor the CSR were related to any other demographic parameters. Moreover, the relation between population changes and BPR as well as that between changes and BPR and CSR together were not significant. 
Table 1 Main population parameters of the reintroduced population of Grey partridge in central Italy from 1995 to 2005

\begin{tabular}{llllcl}
\hline Years & Pair/brood number & Pair density (pairs/km $\left.{ }^{2}\right)$ & Brood production rate & Brood size (arithmetic mean) & Chick survival rate \\
\hline 1995 & -113 & - & - & 6.6 & 38.5 \\
1996 & $89 / 30$ & 3.4 & 33.7 & 12.1 & 78.6 \\
1997 & $157 / 50$ & 5.9 & 31.8 & 6.9 & 35.4 \\
1998 & $141 / 38$ & 5.3 & 26.9 & 3.5 & 14.2 \\
1999 & $114 / 41$ & 4.3 & 36.0 & 8.4 & 49.6 \\
2000 & $160 / 53$ & 6.1 & 33.1 & 7.3 & 44.9 \\
2001 & $177 / 83$ & 6.7 & 46.9 & 5.4 & 25.3 \\
2002 & $124 / 42$ & 4.7 & 33.9 & 5.2 & 26.6 \\
2003 & $107 / 15$ & 4.1 & 14.0 & 7.9 & 48.1 \\
2004 & $64 / 31$ & 2.4 & 48.4 & 6.1 & 34.5 \\
2005 & $61 /-$ & 2.3 & - & - & - \\
\hline
\end{tabular}

Weather effects

Partial correlation analyses showed that higher average temperature in January and absolute minimum temperature in March led to higher pair density in spring $(r=0.842, p=$ $0.009 ; r=0.733, p=0.039$, respectively; TPM $p$ value $=$ 0.023). The relationship with March absolute minimum temperature was linear with the model explaining $71.7 \%$ of the total variance $(Y=5.4+0.4 x, p=0.002)$. We found a negative correlation between BPR and June average temperature $(r=-0.863, p=0.003$; TPM $p$ value $=0.047)$. Brood density, CSR and the change in abundance of spring population from 1 year to the next were not significantly related to any weather variables.

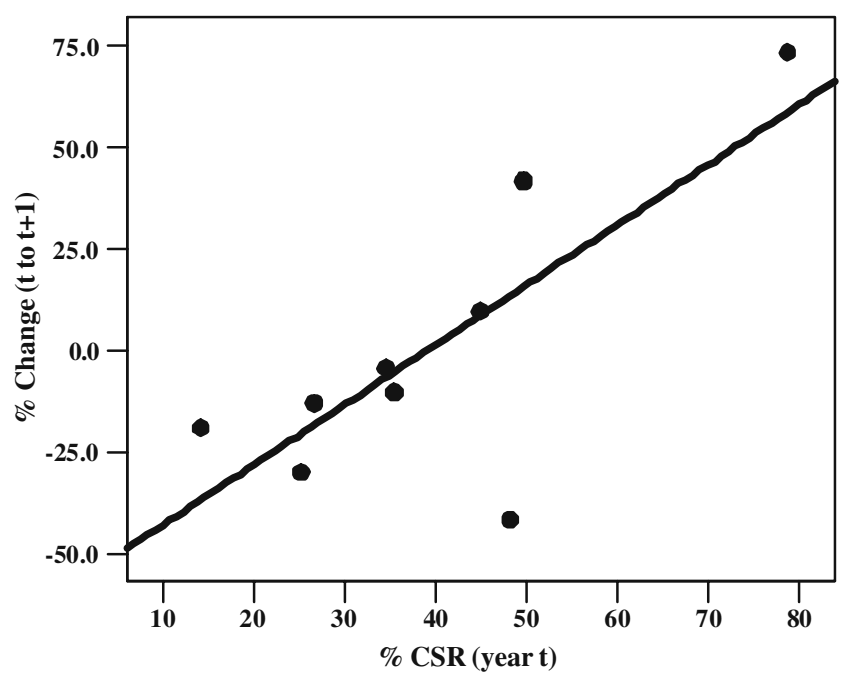

Fig. 2 Annual changes in Grey partridge abundance in relation to annual chick survival rates from 1996 to $2005(Y=-57.8+1.5 x ; F=$ 9.71; $d f=1,7)$

\section{Discussion}

During the study period, the reintroduced population of grey partridges showed an average breeding density that was very low compared to pre-decline populations but intermediate in respect to other grey partridge populations studied in Europe and in North America (Meriggi et al. 1990; Rotella et al. 1996; Panek and Kamieniarz 1998; Panek 2005, Bro et al. 2005). Higher population levels were found only for some areas in northern France and in England (Potts and Aebischer 1994; Aebischer and Ewald 2004; Bro et al. 2005), and lower breeding densities were recorded in Italy, Austria, France, and Finland (Meriggi et al. 1991, 1992; Turtola 1998; Bro et al. 2000; Reitz 2003).

Annual breeding density of our reintroduced population seems to be mainly affected by the juvenile density of the previous year and by the weather. The studies concerning the relationships between weather variables and wild populations of Phasianidae have shown that weather can have direct and indirect effect on the populations. For example, severe winters can reduce the over-winter survival of the adults and the breeding performance of the hens (Church 1980; Potts 1980; Rotella et al. 1996; Draycott et al. 1998; Gabbert et al. 1999). Moreover, cold springs prevent the grass growth with the consequence of a poor nest concealment and higher nest predation rate (Hill and Robertson 1988; Meriggi et al. 1990). Considering the values of the BPR reported by various authors in several researches on population dynamics of the grey partridge in Europe and North America, it is possible to individuate two periods with a marked difference of the BPR range: Until the late 1980s, the reported values of BPR were greater than $50 \%$, whereas from the middle of the $1990 \mathrm{~s}$, most of the studies reported BPRs lower than $40 \%$ and often lower than 35\% (Weigand 1980; Chlewski and Panek 1988; Meriggi et al. 1990, 1991; Montagna and Meriggi 1991; Panek 1997a, 
2005). As found out by Potts (1986) and Panek (1997a, 2005), BPR is often density-dependent, so that this parameter is one of the most important factors determining and regulating the level of population density. The average percentage of pairs reproducing successfully of our reintroduced population was close to that recorded in the last period in declining populations in Europe. In our case, BPR seems not to be density-dependent, and the reasons for a such BPR could be (1) the strong weather effect on both breeding density and BPR that masks BPR density dependence, (2) the interaction between predation, mainly by red foxes in our study area, and quality of nesting cover and (3) the presence of hand-reared birds during the initial period. Contrary to many authors (Potts 1986; Ricci and Garrigues 1986; Reitz 1988; Panek 1997a; Milanov 1998), high early summer temperatures affected negatively the BPR of our population. Recently, especially in Mediterranean countries, the increase in summer temperatures, together with the loss of permanent cover, seems to be responsible for the decrease in productivity and the increase in adult predation (red-legged partridge; Villanùa et al. 2005).

In our population, CSR fluctuated widely, and its values were close to those recorded in Britain, on areas with land management for conservation purposes (Aebischer and Potts 1998; Sotherton et al. 1993). Potts and Aebischer (1994) pointed out that an increase in offspring survival rate could stabilise but not reverse most of the declining populations. In our case, CSR affects the change of breeding population, but no weather conditions explain their annual fluctuations. Probably, other factors interact in determining annual CSRs, as the use of pesticides and herbicides and the predation pressure during breeding seasons despite the predation control (Potts 1986; Panek 1997b; Milanov 1998; Panek 2005). Even if the negative effects of weather on wild populations of Phasianidae can be compensated by higher productivity in favourable years, a series of several negative years acting on a small population can be fatal to the population itself. This is the case of a reintroduced population that can suffer of the typical problems of the small and isolated populations and in which the demographic stochasticity can prevent the recovery (Lacy 1992; Meriggi et al. 2007).

The reintroduction of our population cannot be classified as successful with reference to conservative criteria adopted by Beck et al. (1994). After an initial increase of breeding density, annual fluctuations in brood production and CSRs conditioned negatively the population levels. Weather partially explained annual changes in demographic parameters of our population. For a major comprehension of how weather, resource availability and predation pressure interact to determine reintroduced population levels, the way is to carry out further experiments with a metapopulation approach. This approach allows testing the effects of different habitat improvement, predator control, pesticide and herbicide levels, without endangering the re-established population.

Acknowledgements We are particularly grateful to G.R. Potts for a critical revision that greatly improved an early draft of the manuscript and to Prof. L. Fattorini (University of Siena) for his statistical advice. The study was supported by Tuscany Region, Province of Siena, and Hunting District 19th.

\section{References}

Aebischer NJ, Ewald JA (2004) Managing the UK grey partridge Perdix perdix recovery: population change, reproduction, habitat and shooting. Ibis 146(Suppl. 2):181-191

Aebischer NJ, Kavanagh B (1996) Grey partridge Perdix perdix. In: Hagemeijer WJM, Blair MJ (eds) The EBCC atlas of European breeding birds. Their distribution and abundance. $T \& A D$ Poyser, European Bird Census Council, London, pp 212-213

Aebischer NJ, Potts GR (1998) Spatial changes in Grey partridge (Perdix perdix) distribution in relation to 25 years of changing agriculture in Sussex, U.K. Gibier Faune Sauvage/Game and Wildl 15:293-308

Beck BB, Rapaport LG, Stanley Price MR, Wilson AC (1994) Reintroduction of captive-born animals. In: Olney PJS, Mace GM, Feistner ATC (eds) Creative conservation. Interactive management of wild and captive animals. Chapman \& Cole, London, pp 265-286

Blondel J (1969) Méthodes de dénombrement des populations d'oiseaux. In: Lamotte M, Boulière F (eds) Problèmes d'écologie: l'echantillonage des peuplements animaux des milieux terrestres. Masson, Paris, pp 97-151

Bro E, Deldalle B, Massot M, Reitz F, Selmi S (2003) Density dependence of reproductive success in grey partridge Perdix perdix populations in France: management implications. Wildlife Biol 9:93-102

Bro E, Reitz F, Landry P (2005) Grey partridge Perdix perdix population status in central northern France: spatial variability in density and 1994-2004 trend. Wildlife Biol 11:287-298

Bro E, Sarrazin F, Clobert J, Reitz F (2000) Demography and the decline of the grey partridge Perdix perdix in France. J Appl Ecol 37:432-448

Buner F, Schaub M (2008) How do different releasing techniques affect the survival of reintroduced grey partridges Perdix perdix. Wildlife Biol 14:26-35

Caughley G, Sinclair ARE (1994) Wildlife Ecology and Management. Blackwell Science L.T.V. Oxford, Melbourne, Berlin

Chlewski A, Panek M (1988) Population dynamics of the partridge on hunting grounds of Czempin, Poland. In: Pielowski Z (ed) Proceedings of the common partridge (Perdix perdix L.) international symposium on Polish Hunting Association, Warsaw, pp. $143-156$

Church KE (1980). Grey partridge (Perdix perdix L.) nesting success and brood survival in east-central Wisconsin. M.E.A.S. Thesis, Univ. Wis., Green Bay

De Franceschi P (1988) La situazione attuale dei Galliformi in Italia. Ricerche recenti e ancora in corso. Problemi di gestione e prospettive per il futuro. Supplemento Ricerche Biologia Selvaggina 14:129-168

De Leo GA, Focardi S, Gatto M, Cattadori IM (2004) The decline of the grey partridge in Europe: Comparing demographies in 
traditional and modern agricultural landscapes. Ecol Model 177:313-335

Dowell SD (1992) Problems and pitfalls of gamebirds reintroduction and restocking: An overview. Gibier Faune Sauvage/Game and Wildl 9:773-780

Draycott RAH, Hoodless AN, Ludiman MN, Robertson PA (1998) Effects of spring feeding on body condition of captive ringnecked pheasants in Great Britain. J Wildl Manage 62:557-563

Frampton GK, Dorne JLCM (2007) The effects on terrestrial invertebrates of reducing pesticide inputs in arable crop edges: a meta-analysis. J Appl Ecol 44:362-373

Gabbert AE, Leif AP, Purvis JR, Flake LD (1999) Survival and habitat use by ring-necked pheasants during two disparate winters in South Dakota. J Wildl Manage 63(2):711-722

Garcia LV (2004) Escaping the Bonferroni iron claw in ecological studies. Oikos 105:657-663

Gibbons DW, Hill D, Sutherland WJ (1996) Birds. In: Sutherland WJ (ed) Ecological census techniques. A handbook. Cambridge, Cambridge University Press, pp 227-259

Hill DA, Robertson P (1988) Breeding success of wild and handreared ring-necked pheasants. J Wildl Manage 52:446-450

Lacy RC (1992) The effects of inbreeding on isolated populations: are minimum viable population size predictable? In: P. L. Fiedler, S. K. Jain (eds) Conservation biology. Chapman and Hall, London, pp. 227-296

Matteucci C, Toso S (1986) Note sulla distribuzione e lo status della Starna Perdix perdix in Italia. In: Dessì-Fulgheri F, Mingozzi T (eds) Atti del Seminario di Biologia dei Galliformi. Università della Calabria Arcavacata, Cosenza, pp 29-34

Meriggi A (1989) Analisi critica di alcuni metodi di censimento della fauna selvatica (Aves, Mammalia). Aspetti teorici ed applicativi. Ricerche di Biologia della Selvaggina 83:1-59

Meriggi A, Brangi A, Cuccus P, Mazzoni della Stella R (2002) High mortality rate in a re-introduced Grey partridge population in Central Italy. Ital J Zool 69:19-24

Meriggi A, Mazzoni della Stella R, Brangi A, Ferloni M, Masseroni E, Merli E, Pompilio L (2007) The reintroduction of grey and redlegged partridges (Perdix perdix and Alectoris rufa) in Central Italy: a metapopulation approach. Ital J Zool 74:215-237

Meriggi A, Montagna D, Zacchetti D (1991) Habitat use by partridges (Perdix perdix and Alectoris rufa) in an area of northern Apennines, Italy. Bollettino di Zoologia 58:85-90

Meriggi A, Montagna D, Zacchetti D, Matteucci C, Toso S (1990) Population dynamics of the grey partridge (Perdix perdix) in relation to agriculture and weather in northern Italy. In: Church KE, Warner RE, Brady SJ (eds) Perdix V: grey partridge and ring-necked pheasant workshop. Emporia, Mankato, pp 241 256

Meriggi A, Saino N, Montagna D, Zacchetti D (1992) Influence of habitat on density and breeding success of grey and red-legged partridges. Boll Zool 59:289-295

Milanov Z (1998) Effects of weather on the young: old ratio of grey partridges (Perdix perdix) in central Bulgaria. Gibier Faune Sauvage/Game and Wildl 15:321-329

Montagna D, Meriggi A (1991) Population dynamics of grey partridge (Perdix perdix) in northern Italy. Bollettino di Zoologia 58:151-155

Moran MD (2003) Arguments for rejecting the sequential Bonferroni in ecological studies. Oikos 100:403-405

Neuhauser M (2004) Testing whether any of the significant tests within a table are indeed significant. Oikos 106:409-410

Panek M (1997a) Density- dependent brood production in Grey partridge Perdix perdix in relation to habitat quality. Bird Study 44:235-238

Panek M (1997b) The effect of agricultural landscape structure on food resources and survival of grey partridge Perdix perdix chicks in Poland. J Appl Ecol 34:787-792
Panek M (2005) Demography of grey partridges Perdix perdix in Poland in the years 1991-2004: reasons of population decline. Eur J Wildl Res 51:14-18

Panek M, Kamieniarz R (1998) Agricultural landscape structure and density of grey partridge (Perdix perdix) populations in Poland. Gibier Faune Sauvage/Game and Wildl 15:309-320

Parish DMB, Sotherton NW (2007) The fate of released captive-reared grey partridges Perdix perdix: implications for reintroduction programmes. Wildlife Biol 13:140-147

Pépin D (1983) Utilisation et valeur de diverses methods d'estimation de la densité de la Perdrix rouge (Alectoris rufa) au printemps. Actos XV Congreso Internacional de Fauna Cinegenetica y Silvestre, Trujillo, pp 725-735

Pielowski Z, Pinkowski M (1988) Situation of the partridge population in Poland. In: Pielowski Z (ed) Proceeding of the Common Partridge International Symposium, Poland 1985. Polish Hunting Association, Warsaw, pp 15-32

Potts GR (1980) The effects of modern agriculture, nest predation and game management on the population ecology of the partridges Perdix perdix and Alectoris rufa. Adv Ecol Res 11:1-79

Potts GR (1985) The partridge situation in Italy: a view from Britain. In: Fulgheri FD, Mingozzi T (eds) Biologia dei Galliformi. Problemi di gestione venatoria e conservazione. Dipartimento di Ecologia dell'Università della Calabria, Arcavacata, pp 9-13

Potts GR (1986) The partridge: pesticides, predation and conservation. Collins, London

Potts GR (2008) Global Biodiversity Conservation: We Need More Managers and Better Theorists. In: Fulbright TE, Hewitt DG (eds) Wildlife science. linking ecological theory and management applications. CRC, London, pp 43-63

Potts GR, Aebischer NJ (1994) Population dynamics of the grey partridge Perdix perdix 1793-1993: monitoring, modelling and management. Ibis 137(Suppl. 1):29-37

Putaala A, Hissa R (1998) Breeding dispersal and demography of wild and hand-reared grey partridges Perdix perdix in Finland. Wildlife Biol 4:137-145

Reitz F (1988) Un modèle d'estimation de la réussite de la reproduction de la Perdrix grise (Perdix perdix L.) a partir des conditions climatiques. Gibier Faune Sauvage/Game and Wildl 5:203-212

Reitz F (2003) Le statut communal de la Perdrix grise et de la Perdrix rouge en France: résultats d'une equete. Gibier Faune Sauvage/ Game and Wildl 260:14-20

Ricci JC (1985) Influence de l'organisation sociale et de la densité sur les relations spatiales chez la Perdix rouge. Conséquences démographiques et adaptatives. Revue d'Ecologie (La Terre et al Vie) 40:53-84

Ricci JC, Garrigues R (1986) Influence de certaines caractéristiques des agro-systèmes sur les populations de perdrix grises (Perdix perdix L.) dans la région nord-bassin parisien. Gibier faune Sauvage/Game and Wildl 3:369-392

Rotella JJ, Ratti JT, Reese KP, Taper ML, Dennis B (1996) Long-term population analysis of Gray partridge in eastern Washington. J Wildl Manage 60(4):817-825

Sokos CK, Birtsas PK, Tsachalidis EP (2008) The aims of galliforms release and choice of techniques. Wildlife Biol 14:412-422

Sotherton NW, Robertson PA, Dowell SD (1993) Manipulating pesticide use to increase the production of wild game birds in Britain. In: Church KE, Dailey TV (eds) Quail III: National Quail Symposium. Department of Wildlife and Parks, Pratt, pp 92-101

Tucker GM, Heath MF (1994) Birds in Europe: their conservation status. Birdlife International, Series 3, Cambridge

Turtola A (1998) Improving Grey partridge (Perdix perdix) habitat by set-aside management in Filand. Gibier Faune Sauvage/Game and Wildl 15:455-562 
Villanùa D, Acevedo P, Esubero MA, Javier M, Gortazar C (2005) Factors affecting summer densities of red-legged partridge (Alectoris rufa). In: Pohlmeyer K (ed): Extended Abstracts of the 27th Congress of the International Union of Game Biologist, Hannover 2005. DSV-Verlag, Hamburg, pp 195-197

Weigand JP (1980) Ecology of the Hungarian partridge in northcentral Montana. Wildl Monogr 74:1-106
Watson M, Aebischer NJ, Potts GR, Ewald JA (2007) The relative effects of raptor predation and shooting on overwinter mortality of grey partridges in the United Kingdom. J Appl Ecol 44:972982

Zaykin DV, Zhivotovsky LA, Westfall PH, Weir BS (2002) truncated product method for combining $p$-values. Genet Epidemiol 22:170-185 